\title{
A monarquia entre republicanos
}

Tiago Losso

\section{Resumo}

A teoria política contemporânea tem sido alimentada de maneira crescente por formulações alicerçadas no ideário republicano. Teóricos atuais têm sustentado que essa tradição de pensamento encontra sua gênese nas noções políticas e morais correntes durante o século final da República romana. Minha intenção neste artigo é realizar uma avaliação dos três primeiros livros da História de Roma, de Lívio, e dos dois primeiros livros do Tratado da República, de Cícero, investigando a importância da monarquia em seus respectivos argumentos. Defendo que uma precisa compreensão do significado da etapa inicial da história da cidade e desse princípio constitucional para a ideia de Constituição Mista pode enriquecer a visão sobre elementos fundamentais da tradição republicana de pensamento político.

Palavras-chave: Teoria política. Republicanismo. Monarquia. Roma.

\section{Introdução}

Nos últimos trinta anos, houve um retorno ao estudo dos temas relacionados ao republicanismo no âmbito da Teoria Política. Em grande medida, esse retorno deve-se aos trabalhos do filósofo político Philip Pettit e do historiador das ideias políticas Quentin Skinner, eixos de um debate acalorado sobre o conceito de liberdade no âmbito da teoria política contemporânea. Ambos advogam existir uma noçáo de liberdade que náo seria adequadamente compreendida como negativa ou positiva nos precisos termos propostos por Isaiah Berlin (2012). Essa noçáo seria distinta das anteriores, por conter ambos os elementos ou por ser uma variante específica da forma negativa, sendo, portanto, percebida e apresentada em termos de "náo dominação" (PETTIT, 1999; SKINNER, 2002). Localizável nos escritos de autores associados ao republicanismo, tal noçáo estaria no âmago das noçóes políticas e morais compartilhadas pelos

I Doutor em Ciências Sociais pela Universidade Estadual de Campinas (Unicamp), Campinas, São Paulo, Brasil. Pesquisador do Núcleo de Estudos do Pensamento Político e Professor do Departamento de Sociologia e Ciência Política no Centro de Filosofia e Ciências Humanas (CFH) da Universidade Federal de Santa Catarina (UFSC), Florianópolis, Santa Catarina, Brasil. E-mail: tiagolosso@gmail.com. 
romanos durante a república e teria sido preservada no Digesto, ${ }^{2}$ sendo retomada pelos pensadores da política durante o Renascimento e princípios da modernidade, marcando por fim toda uma série de autores modernos até o seu ocaso, em princípios do século XIX, de acordo com a genealogia proposta por Philip Pettit (1999).

A antiga Roma sob a república é tida como o marco inicial da tradição de pensamento político associado ao republicanismo, tanto em termos institucionais quanto intelectuais. ${ }^{3}$ A ideia de uma constituição mista é ponto fundamental para a teorização anunciada por Políbio, cristalizada em $D e$ Re Publica ${ }^{4}$ por Marco Túlio Cícero e mobilizada em Ab Urbe Condita 5 por Tito Lívio. No entanto, deve ser apontado que o acesso ao pretenso pensamento republicano clássico é repleto de dificuldades. A definiçáo mesmo dos elementos que comporiam a tradiçáo é foco de discussáo. Tome-se o caso do Digesto.

Uma primeira distinçáo reside no fato de que o Digesto náo pode ser considerado equivalente ao pensamento republicano clássico, pelo menos no tocante à ideia de liberdade (WIRSZUBSKI, 1968; MADDOX, 2002). Mesmo que o Digesto componha o pensamento republicano clássico, o é apenas em termos jurídicos. Logo, tomá-lo como fonte é simplificar uma expressáo intelectual complexa, não restrita a argumentos jurídicos. Se o Digesto não é parte integrante do pensamento republicano clássico, deve ser lido como expressão de outro momento histórico e intelectual.

Além dos termos para definir a tradição republicana, tem-se na variedade de autores que formariam o ponto inicial do republicanismo um desafio de interpretação. Entre Salústio, Cícero e Lívio, é possível encontrar não somente

20 Digesto é uma compilação, não totalmente sistemática, de fragmentos e citações dos antigos juristas do período clássico (séculos I-III d.C.) encomendado pelo Imperador Justiniano a uma comissão de juristas e professores de direito de Constantinopla, liderados por Triboniano, em meados do século VI da Era Cristã (530-533). (PETIT, 2003).

3 No caso especifico de Skinner e Pettit: "[...] Roman political thought is the primary source of subsequent republican political thought, especially an account of republican political thought understood in opposition to civic humanism and to liberalism. Roman political thought provides an historical and conceptual framework from which subsequent republican political thought derives, and also provides a rich variety of ideals and figures, historical and literary, on which subsequent republicans would draw." (KAPUST, 201 I, p. 13).

4 Salvo quando indicado, todas as citações de De Re Publica serão de Tratado da República (CíCERO, 2008),

5 Salvo quando indicado, todas as citações de Ab Urbe Condita (AUC) serão de História de Roma (LÍVIO, 1989). 
perspectivas distintas sobre pontos importantes da teoria política republicana (p. ex., o papel conferido ao povo na conduçâo do governo), como também visóes desconcertantes ao leitor contemporâneo.

O papel da monarquia na história da cidade e do elemento monárquico na ideia de constituiçáo mista constituem-se chaves para demonstrar a existência de desafios inerentes ao estudo dos antigos autores romanos. Tome-se o caso de Salústio, mobilizado por Skinner e Pettit para advogar a noção republicana de liberdade. Podem ser dirigidas objeçóes à interpretaçáo de Quentin Skinner sobre a perspectiva de Salústio acerca da liberdade civil, como faz Walker ao afirmar que poderia ser localizada em escritos de Salústio a sugestáo de que os cidadáos de Roma experienciaram algum nível de liberdade mesmo durante a Monarquia e foram vítimas de uma tirania sob Sula (WALKER, 2006). Os autores contemporâneos estariam a tratar de uma leitura dos antigos feita pelos modernos, e náo dos antigos em si (WALKER, 2006).

A caracterizaçáo de ideias republicanas como visceralmente inimigas da monarquia é um elemento tipicamente moderno que acaba sendo decalcado nos escritos dos antigos, gerando inclusive a relutância em enquadrar Montesquieu na pretensa tradiçấo republicana, em grande medida devido à sua evidente simpatia por regimes monárquicos (DOUGLASS, 2012). Defendo que isso ignora uma noçáo compartilhada pelos romanos sobre as qualidades do período monárquico e os desdobramentos possíveis para se pensar o papel do princípio monárquico nas teorias sobre liberdade e formas de governo. Relacionado a esse papel relevante do elemento monárquico, deve ser considerado que a expulsáo dos reis de Roma náo marca senáo um lento processo de montagem institucional que conferirá à constituição de Roma as características louvadas por Políbio e aceitas como definidoras mesmo do que significa um governo livre entre os autores romanos antigos.

Utilizar o termo constituição em referência à realidade da Roma Antiga é uma escolha passível de crítica. ${ }^{6}$ Segundo Straumann, é perfeitamente razoável pensar em uma constituição romana desde que o conceito seja compreendido como um conjunto de normas mais enraizadas (entrenched) que outras logo, com menos possibilidade de alteraçáo - e com influência significativa no

6 O estágio desta discussão pode ser conferido em Straumann (2011). 
governo das instituiçôes através das quais o poder é exercido (STRAUMANN, 2011). Sendo esse ordenamento significativo tanto do ponto de vista intelectual quanto institucional, interpretar adequadamente seus contornos é relevante para uma efetiva compreensáo dos debates sobre liberdade na teoria política contemporânea. ${ }^{7}$ Quentin Skinner é um caso exemplar, com sua insistência em localizar na Roma Antiga a principal influência das formulaçóes da tradição neorromana de princípios da modernidade, que lega um corolário teórico que define liberdade em termos de não dominaçáo.

Ao acompanhar os debates intelectuais de princípios da modernidade, Skinner alega obter teoria política secretada de seus estudos históricos, fornecendo aos contemporâneos um universo de referências mais largo para considerar seus dilemas políticos particulares. Ao localizar a gênese da tradiçáo republicana na antiga Roma, no entanto, Skinner parece ignorar a dinâmica de elementos-chave da tradiçáo que pretende historiar. Um ponto que une esses críticos é uma possível incompreensão de Skinner sobre elementos fundamentais da realidade política e intelectual de Roma nos estertores da república. Traços constitucionais da Roma republicana sáo elencados no sentido de questionar a efetiva relação entre as formulaçóes republicanas, moderna e contemporânea, e a realidade que pretensamente a teria gestado ${ }^{8}$ (ANDO, 2010; KAPUST, 2004; MADDOX, 2002; WALKER, 2006).

Esse acesso a escritos do passado requer alguns cuidados. De maneira geral, tem-se a exigência de recuperar o dito no passado em seus próprios termos. A anacronia desfoca o escrito analisado, e tanto sua compreensão quanto sua mobilizaçáo para solucionar dilemas contemporâneos ficam comprometidas. No caso específico da tradiçáo republicana de pensamento político, deve ser acrescentado outro complicador. Sendo uma tradiçáo 9 composta de diversas camadas, cultivada ao longo de séculos, abrem-se eventuais distâncias entre a

7 Um argumento pormenorizado defendendo este tipo de preocupação está em Kapust (2004, p. 379-380).

8 Em relação à teoria contemporânea, o argumento é exemplarmente exposto no trecho seguinte: "If virtue is linked to republican liberty, and if republican liberty may be compatible with the existence of orders or groups that are paternalistic and tend to disempower the citizenry while leaving them free, then I think we would do well to rethink the way we describe republican liberty, and ask if it is a shield or a sword. I suggest that we would do well in asking this question given that what we see in the earliest history of republicanism seems to be quite different from what contemporary advocates of normative republicanism would urge liberals to consider." (KAPUST, 2004, p. 40I).

9 Sobre o conceito de tradição que utilizo, ver Bevir (2000). 
narrativa mestra da tradiçáo e os fatos históricos, bem como entre as narrativas (concorrentes e concordantes) no seio da própria tradição. Em relação à primeira distância, assumo que meu interesse principal é com a narrativa que os romanos escreveram sobre si próprios. ${ }^{10}$ Estou interessado nos contornos da ideologia elaborada pelos romanos antigos, e náo em sua acurácia, pois foi o cultivo dessa ideologia que constituiu a tradiçáo republicana de reflexão política, tradiçáo esta que náo desconfiou, a exemplo dos antigos romanos, da pertinência e dos termos da história de Roma. Para lidar com a segunda distância apontada, vou cotejar as duas narrativas aqui analisadas, buscando estabelecer o significado das distinçóes relevantes para a conformação de uma espécie de narrativa básica da compreensão dos antigos romanos sobre o significado de seu mundo.

Deixando agora de lado as implicaçóes do retorno aos antigos autores latinos para a teoria política contemporânea, pretendo explorar elementos da constituiçáo mista nos escritos clássicos do republicanismo através da leitura e interpretaçáo dos três primeiros livros de $A b$ Urbe Condita, de Tito Lívio, e dos dois primeiros livros de De Re Publica, de Marco Túlio Cícero. Justifico o esforço ressaltando a repercussão de ambos os autores na tradiçáo intelectual ocidental e sua lógica contribuiçáo para a reflexáo política moderna e contemporânea. O exemplo evidente dessa reverberaçáo é Maquiavel e sua leitura de Lívio. Além da importância enquanto autores tornados clássicos, aponto as qualidades intrínsecas aos seus escritos, que, a despeito de apresentarem respostas para dilemas políticos particulares, sáo bons retratos de um panorama intelectual considerado relevante pela crítica contemporânea, quando empenhada em enfrentar seus próprios dilemas.

Em sua História, Lívio trata de um período rico da formaçáo de Roma: da chegada de Enéias no reino de Latino até a publicaçáo da Lei das XII Tábuas, passando pelo crescimento durante a monarquia, a expulsáo dos reis, a criaçáo dos Tribunos da Plebe, o envio da legação à Hélade e a instituiçáo dos Decênviros. Cícero apresenta suas consideraçôes sobre a coisa pública em $\mathrm{De}$ Re Publica, num tratado em forma de diálogo que emula Platão. Os dois primeiros

10 Mesmo a hipercrítica do século XIX, que defendia existir grande divergência entre os registros mitológicos dos antigos romanos e sua verdadeira história, estão hoje em refluxo. Recentes descobertas arqueológicas indicam, por exemplo, que a ocupação permanente das colinas de Roma deu-se no século VIII a.C., datação consoante com a dos registros literários antigos (PEREIRA, 2002). 
livros de seu tratado foram escritos antes da definiçáo do formato definitivo, sendo onde se localiza a parte mais rica do arrazoado de Cipiáo Emiliano Africano, quando sáo apresentados os principais elementos dos aspectos morais e políticos pretensamente característicos das ideias correntes na Roma dos anos finais da República, em especial as consideraçóes sobre os diferentes tipos de constituiçáo e a originalidade da constituiçáo de Roma.

Acredito ser possível apresentar evidências textuais que justifiquem alegar que o tipo de governo elogiado por esses dois autores romanos era considerado produto dos primeiros três séculos da história da cidade, através do estabelecimento de instituiçóes que canalizaram tensóes políticas entre diferentes setores sociais, permitindo um equilíbrio político virtuoso e garantidor da liberdade civil. Em suma, uma Constituição específica. Ainda, que o princípio constitucional monárquico é fundamental nessa engenharia republicana, num equilíbrio perfeito com os princípios aristocrático e democrático.

\section{A escolha de Cipião}

A gênese e oscilação da "relevância" de uma tradição nomeada modernamente como republicana podem ser acompanhadas na trajetória não só das letras latinas no mundo ocidental, como também na circulação dos escritos de Marco Túlio Cícero, o autor paradigmático da pretensa tradiçáo republicana de reflexão sobre a política.

Seu tratado sobre a coisa pública (De Re Publica) surge após seu afastamento da vida pública, com o Primeiro Triunvirato. Cícero pretende compor uma nova República, inspirado em seu "amado Platáo" (CíCERO, 1928, p. 2). A escrita começa em 54 a.C., mesmo que a dataçâo possa ser recuada até o seu Consulado (63 a.C.) ou mesmo antes (CÍCERO, 1928, nota 2). Evidências seguras indicam, no entanto, que De Re Publica circulava em Roma em 51 a.C. (CÍCERO, 1928, p. 3). Não apenas De Re Publica, mas toda uma série de escritos políticos será composta por Cícero nesse período, estando entre eles De Legibus e De Officiis (WOOD, 1991).

Tratado da República e Dos deveres sáo peças centrais do pensamento político e social de Cícero, tendo ainda a peculiaridade de serem os únicos do gênero escritos nos estertores da República e mesmo uns dos primeiros escritos em latim a versar especialmente sobre política (WOOD, 1991). Se Cícero 
é o autor que inaugura a tradiçáo republicana de reflexáo sobre a política, De Re Publica é sua obra fundamental. No entanto, só foi lida pelos autores modernos que viveram depois de 1820, quando sua parte fundamental foi descoberta na Biblioteca do Vaticano (WOOD, 1991; CÍCERO, 1928; PEREIRA, 2002). Até entáo, apenas o sexto livro do tratado, Sonho de Cipião, era conhecido pelos modernos.

O diálogo tem lugar durante as férias latinas de 129, e o estilo é uma referência evidente à República de Platáo. O prefácio do próprio Cícero introduz uma série de personagens do Círculo dos Cipióes, ${ }^{11}$ sendo o principal interlocutor Cipiáo Emiliano Africano, neto adotivo do Africano vitorioso em Zama, o arquétipo ciceroniano do melhor romano. General que conquista seu cognome, íntimo do conhecimento grego, instruído por Políbio, é por suas palavras que Cícero apresentará seu tratado sobre a coisa pública.

O grego Políbio é fundamental para a elaboraçáo das ideias políticas de Cícero, propondo premissas que serão acatadas náo somente por Cícero, mas por toda a sua geraçáo. Um ponto é a caracterizaçáo da política republicana original de Roma como produto das vicissitudes da cidade imersa na dinâmica do Mediterrâneo Antigo, e náo como uma teorizaçáo elaborada posteriormente (BALOT, 2010). O tutor de Cipiáo Emiliano credita ainda o sucesso da expansão romana ao equilíbrio obtido pela sua constituição, fruto de uma mistura entre os princípios monárquico, aristocrático e democrático (BALOT, 2010). A essa caracterização da constituição romana segue-se o estabelecimento do caráter típico de um romano, exemplificado na figura de seu pupilo, o segundo Cipião Africano: bravura aliada à moderaçáo, justiça e racionalidade (BALOT, 2010). Ao escolher Cipiáo Emiliano Africano como o principal interlocutor de seu diálogo sobre a coisa pública, Cícero está mobilizando Políbio, dele extraindo parte do substrato necessário para a elaboração de seus argumentos.

Em De Re Publica, Cipiáo é instado por Lélio a discorrer sobre as artes úteis ao governo da cidade. Lélio afirma que assim deseja por ser melhor contar com as impressóes de um estadista importante do que com as de qualquer outro, e também por ter Cipiáo conversado sobre tais assuntos com Panécio

II Sobre este círculo, ver Pereira (2002, p. 58-62). 
na companhia de Políbio, apresentando a constituição de seus antepassados como a melhor entre todas (Tratado da República, 1.34). Cipião aceita o convite, esclarecendo que deve ser ouvido como alguém que, apesar de não ser completamente ignorante sobre as ideias gregas nem estar disposto a dar-lhes sempre preferência, é um romano antes de tudo, instruído mais pela experiência e pelas liçóes domésticas que pelos livros (Tratado da República, 1.36).

Cipiáo inicia seus comentários precisando o tema que será abordado: a coisa pública: "Portanto, res publica 'Coisa Pública' é a res populi 'Coisa do Povo'. E povo não é um qualquer ajuntamento de homens congregado de qualquer maneira, mas o ajuntamento de uma multidão associada por consenso jurídico e por uma comunidade de interesses." (Tratado da República, 1.39), ${ }^{12}$ definiçáo que será repetida em trecho subsequente (Tratado da República, 1.41). Qualquer comunidade assentada nesses termos, prossegue, pode ser governada por um homem, por alguns ou por muitos, nomeando cada um dos tipos de governo respectivamente como monarquia, aristocracia ou democracia. Cada uma dessas opçóes parece no mínimo aceitável, sendo que cada um pode ser ainda superior aos demais, mas todos possuem condiçóes de manter um governo estável (Tratado da República, 1.42), desde que em suas formas normais, pois cada um engendra perigos ao governo, principalmente quando em suas manifestaçóes degeneradas (Tratado da República, 1.44). Então, Lélio interrompe Cipiāo, perguntando: "Contudo, se náo te causa incómodo, destas três formas de constituição, gostaria de saber qual julgas a melhor." (Tratado da República, 1.46). A interpretação da resposta de Cipião ajudará a compreender o papel que cabe à monarquia na ideia de Constituiçáo Mista conforme descrita e prescrita por Cícero.

A resposta inicia-se com a consideração de que cada tipo de governo emerge do caráter de quem governa e que apenas onde o povo governa existe liberdade. Cipiáo sequer considera, por evidente, a liberdade sob a monarquia. Se o povo náo pode aspirar a ocupar magistraturas e participar ativamente do governo, náo há liberdade para o conjunto de cidadáos. Considerando-se que linhas antes Cipiáo estabelece que, se a liberdade náo for a mesma para todos,

12 Transcrevo uma nota feita pelo tradutor, explicando o uso de termos em itálico, seguidos de possíveis traduções: "Considerando a dificuldade de traduzir certas noções e conceitos, a existência de discussões etimológicas que só se compreendem na própria língua de origem, e a possivel pouca familiaridade de alguns leitores com estas circunstâncias, por vezes conservei o termo latino seguido da possivel tradução entre vírgulas altas, como optimates 'aristocratas', patres 'pais, patricios, senadores." (Tratado da República, Notas Prévias, p. 9). 
náo pode ser assim nomeada, o povo afastado do governo da coisa pública compromete a liberdade da comunidade (Tratado da República, 1.48). Segue-se um arrazoado defendendo a participação popular na condução do governo, impedindo inclusive que cidadáos ricos ocupem proeminência na tarefa, novamente comprometendo a liberdade de todos. Sendo toda comunidade política fundada na lei, as garantias legais devem ser iguais a todos. Mesmo que seja impossível equalizar capacidades individuais ou riqueza, os direitos legais devem ser iguais entre cidadãos de uma mesma comunidade política: "O que é, de facto, uma cidade senáo uma sociedade de direito de cidadáos [...]" (Tratado da República, 1.49).

Os capítulos seguintes seguem sem a resposta, preferindo Cipião prosseguir com consideraçóes sobre convenientes e inconvenientes de cada tipo de governo. Quando se referindo ao princípio monárquico, Cipiáo distingue claramente o bom e o degenerado governo de um. O princípio de sua consideraçáo é apontar o equívoco do uso do termo rei para nomear governantes que antes mereceriam ser nomeados tiranos (Tratado da República, 1.50). O capítulo 51 começa equiparando uma comunidade que escolhe seus governantes ao acaso a um barco cujo leme está com um passageiro sorteado. Quando, então, a comunidade escolhe não os seus melhores para o governo, mas os mais ricos ou de ilustre nascimento, desconsiderando as virtudes, têmse um governo corrompido. $\mathrm{O}$ arremate do argumento é claro: "[...] náo existe espécie de constituiçáo mais disforme do que aquela em que os mais ricos sáo considerados os melhores" (Tratado da República, 1.51).

Impaciente com a demora da escolha de Cipião, Lélio faz nova interrupção, insistindo: "Afinal, ó Cipião, qual desses três tipos, mais recomendas?" (Tratado da República, 1.54). Alertando que náo aprova nenhuma delas em separado, preferindo um governo que tenha a participação de todas, Cipiáo responde:

Com justeza perguntas 'desses três tipos, qual mais recomendo', pois que, separadamente, por si mesmo, não recomendo nenhum deles. A cada um anteponho um outro que seja a fusão de todos eles. Mas se «tivesse dè dar minha recomendação a um só, e simples, «recormendaria o régio .... é designado neste passo, ocorre o nome quase paternal de rei, por este se ocupar dos seus cidadãos como se fossem filhos e os conservar com mais afercto do que .... sendo protegidos pela diligência de um único varão, excelente e superior. (Tratado da República, 1.54). ${ }^{13}$

13 As letras entre sinal de ângulo indicam tentativa de reconstituição do texto; os quatro pontos indicam lacuna no texto original (Tratado da República, Notas Prévias, p. 9). 
$\mathrm{Na}$ sequência, Cipiāo apresenta os argumentos de pretensos defensores do governo de alguns e do governo de muitos, compelindo Lélio a afirmar que a não solução desse ponto implicaria a impossibilidade de prosseguir a discussão. Cipiáo entáo principia novo argumento (Tratado da República, 1.55). O primeiro passo: é reconhecido que os deuses possuem reis e são governados por um só, incutindo nos homens a ideia da excelência da monarquia (Tratado da República, 1.56). O testemunho disso seria a existência de reis em Roma num período não muito recuado da história: "Se, pois, homens prudentes e nem sequer muito antigos decidiram ter reis, entáo estou a usar testemunhas nem muito antigas, nem desumanas, nem selvagens." (Tratado da República, 1.58). A defesa da monarquia é coroada, então, com duas questóes propostas por Cipiáo a Lélio: náo é justo sujeitar desejos e paixóes ao governo unitário da razáo? Se assim o é no que diz respeito à alma do homem, náo seria diferente nas comunidades políticas. Além disso, a quantas pessoas Lélio confiava a ordenação de seus negócios particulares e o cuidado da sua casa em Roma? Com a resposta de Lélio indicando que apenas um o fazia, Cipião retruca: "Porque é que tu, afinal, não concordas que também num Estado «mesımíssimo domínio de um só, desde que justo, é o melhor” (Tratado da República, 1.61). Cipiāo prossegue estabelecendo o primado de um único comando de governo, louvando reis justos como os governantes perfeitos (Tratado da República, 1.63). Retomando a defesa de seu tipo preferido de governo, Cipiáo passa entáo a considerar as comoçóes públicas que costumam agitar comunidades políticas, mesmo sendo possibilidade remota em sua constituiçáo preferida (Tratado da República, 1.65).

Um rei pode ser sucedido por um tirano, e a melhor das formas de governo se torna a pior. A cidade, entáo, pode ser tomada pelos grandes ou pela multidão, desde que mantenha o juízo sereno. Ou a multidão pode depor, exilar ou matar magistrados justos e virtuosos, instalando a licença: “[...] os ânimos dos cidadáos acabam por tornar-se de tal modo altivos e susceptíveis que, ao mínimo uso da força pelo poder, se irritam e náo o conseguem suportar. Daí começarem também a ignorar as leis, para ficarem absolutamente sem senhor algum." (Tratado da República, 1.67). ${ }^{14} \mathrm{O}$ argumento apoiado no

14 Trata-se, segundo Cipião, de um trecho de Platão. Comparar com: "Ora, vês o resultado de todos esses abusos acumulados? Concebes, efetivamente, que tornam a alma dos cidadãos de tal modo assustadiça que, à menor aparência de coação, estes se indignam e se revoltam? E chegam por fim, bem sabes, a não mais se preocupar com leis escritas ou não escritas, a fim de não ter absolutamente nenhum senhor." (PLATÃO, A República, 564e). 
livro VIII d'A República de Platáo encerra-se narrando entáo o caminho que engendra o tirano (Tratado da República, 1.68).

Em seguida, descreve as diversas mudanças de governo pelas quais uma comunidade política pode passar, agora claramente inspirado em raciocínio disponível na História de Políbio: "Assim, como se fosse uma bola, tiram a forma da constituiçáo uns dos outros - os tiranos aos reis, e àqueles os cidadáos de primeira ou os povos, a estes as facçóes ou os tiranos -, e jamais se mantém por muito tempo a mesma forma de constituiçáo." (Tratado da República, 1.68). Repetindo que a monarquia é seu tipo de governo simples preferido, Cipiáo afirma claramente que um governo que surja da mistura de cada uma das formas primárias é indiscutivelmente a melhor das formas conhecidas. ${ }^{15}$ A mistura é superior, desde que mantenha elementos das formas simples, inclusive da monarquia: "De facto, parece bem que exista na constituição algo superior e real, que haja algo concedido e atribuído à autoridade dos cidadáos de primeira, que haja algumas coisas reservadas à decisão e à vontade da multidão." (Tratado da República, 1.69). Essa constituiçáo seria a herdada pelos romanos de seus antepassados. Cipiáo entáo afirma que vai provar sua afirmação tomando Roma como exemplo, tema do livro seguinte do tratado de Cícero.

Sendo a constituição de Roma produto de sucessivas geraçóes de cidadáos, e para bem conhecer o assunto sobre o qual trata agora (a excelência da constituiçáo romana), Cipiáo volta sua atençáo para a história da cidade (Tratado da República, 2.3). ${ }^{16}$ Após louvar a escolha do lugar, Cipiāo apresenta a construção da comunidade política, chamando a atenção para o fato de Rômulo ter escolhido os pais para com eles governar, dispondo de sua autoridade e conselhos, além de respeitar os auspícios oferecidos pelos augures (Tratado da República, 2.14), ${ }^{17}$ arrematando que: "Com tal, antes de tudo, Rómulo viu

15 "Sendo assim, ¿dos` três primeiros tipos, em meu entender, o preferivel é de longe o régio; mas ao régio será preferivel um que seja equilibrado e temperado com as três primeiras formas de constituição." (Tratado da República, 1.69).

16 Trecho em que o autor latino indica o contraste com as letras gregas: "Mais facilmente, porém, eu satisfarei o nosso propósito [discorrer sobre a boa constituição] se vos mostrar o nosso Estado a nascer, a crescer, adulto e já firme e robusto, do que se criar um para mim, como Sócrates e Platão." (Tratado da República, 2.3).

17 Aqui, deve ser indicada uma discrepância cronológica entre a História de Cícero e aquela escrita por Livio, no tocante ao estabelecimento desse conselho régio. Cícero indica que o conselho foi escolhido por Rômulo e Tácio (rei sabino que divide o trono com Rômulo após a celebração da paz entre os povos, em litígio desde o rapto das jovens sabinas pelos romanos), ao passo que em Livio a criação do conselho é um dos primeiros 
e decidiu o mesmo que Licurgo pouco antes tinha visto em Esparta: que as cidades seriam melhor governadas e regidas sob o comando de um só e sob um poder régio se, à força dessa dominaçáo, fosse associada a autoridade de algo óptimo (sc. aristocrático).” (Tratado da República, 2.15). ${ }^{18}$ Após lançar os pilares da comunidade política romana, Rômulo morre (Tratado da República, 2.20) e os patrícios tentam entáo governar. O povo, no entanto, saudoso de seu rei, exige outro (Tratado da República, 2.23). Cipiáo passa, entáo, a considerar a sabedoria dos antigos romanos, que notaram ser periclitante confiar na progênie como justificativa para ocupar o trono, resolvendo entáo elegê-lo, dando preferência à virtude e sabedoria na escolha dos reis (Tratado da República, 2.24). Ao enumerar os feitos de cada um dos reis que sucedem Rômulo, Cícero está colaborando para o estabelecimento de uma narrativa mestra sobre a história de Roma, que está também exposta na História de Lívio. Ao longo de diversos reis e geraçóes de romanos, foi estabelecida a melhor de todas as constituiçóes. Lélio lembra Catão ao concordar com Cipiáo: "Torna-se agora mais claro aquele ditto de Catáo: que a constituiçáo do (nosso) Estado náo foi obra de um só tempo ou de um só homem. É, de facto, evidente quão grande se torna o acréscimo de coisas boas e úteis, por cada rei." (Tratado da República, 2.37). Ao narrar a sucessáo de reis, Cipiáo indica as contribuiçóes de cada um para a construção de Roma, e finalmente chega ao rei que tornou a palavra odiosa aos romanos: Tarquínio, o Soberbo.

Um único rei foi capaz de transformar a melhor das constituiçóes na pior entre todas, tornando a palavra "rei" odiosa entre os romanos. ${ }^{19}$ Sua expulsáo marca o início da construçáo da comunidade política livre que Roma será. As instituiçóes que formarâo a res publica romana foram lançadas durante a monarquia, e, agora sem reis, a cidade precisará finalizar o processo. Após a expulsão dos Tarquínios, prossegue Cipião:

atos de Rômulo ao fundar a cidade, antes, portanto, do Rapto da Sabinas e da partilha do trono entre Rômulo e Tácio (como será explorado em trecho seguinte deste artigo). A divergência cronológica não abala meu argumento, já que o papel de contrapeso do conselho é equivalente nas duas narrativas. Sobre o Rapto da Sabinas e os eventos relacionados, ver Pereira (2002, p. 28-29).

180 uso do termo entre parênteses é explicado pelo tradutor: "Para diminuir o número de notas, em certos casos inseri no corpo da tradução alguma explicitação, que coloquei entre parênteses curvos, como nem Quinto (sc. Fábio) Máximo." (Tratado da República, Notas Prévias, p. 9).

19 "Passados, pois, esses duzentos e quarenta anos de realeza, até um pouco mais com os interregnos, e expulso Tarquínio, o povo Romano ficou com tanto ódio ao nome de rei como com saudade ficara de Rómulo depois do seu óbito, ou melhor, da sua partida. E tal como não pudera, então, passar sem rei, assim também, expulso Tarquínio, não podia ouvir o nome de rei." (Tratado da República, 2.52). 
Portanto, nesta altura, o senado manteve o Estado na seguinte situação: num povo livre, poucas coisas eram geridas através do povo, e a grande maioria era gerida pela autoridade e de acordo com as práticas e costumes do senado; e os cônsules detinham um poder somente anual, régio por sua própria natureza e por direito. (Tratado da República, 2.56).

Note-se que o poder real é mantido após a expulsão dos reis de Roma. A comunidade livre será entáo mantida e incrementada, ao longo de um período formativo que vai até a publicação da Lei das XII Tábuas. A constituiçáo louvada por Cícero através da exposiçáo de Cipiáo náo foi, portanto, produto de um gênio legislador ou estabelecida de supetáo. Lançadas as suas bases durante a monarquia, a república romana será produto da história da cidade. Uma história narrada em detalhes por Tito Lívio, décadas depois do aparecimento d'A República de Cícero. É para a História de Lívio que agora me volto, tentando relacionar suas impressóes com aquelas expressas por Cícero e estabelecer um quadro satisfatório de referências para aquilatar a importância do princípio monárquico na constituiçáo mista nos escritos dos antigos romanos.

\section{A construção de uma comunidade política livre}

Sabe-se menos sobre a vida de Tito Lívio do que o conhecido sobre Cícero. Nascido em 59 a.C. em Patavium (a moderna Pádua), Lívio parece ter crescido numa família aristocrata em uma das mais importantes cidades da Itália de seu tempo, tornada uma municipalidade de Roma em 49 a.C. Sua história de Roma, Ab Urbe Condita (AUC), é célebre por pelo menos dois motivos. Ocupa um lugar de destaque na lista dos escritos fundamentais do pensamento político republicano e foi base para a elaboraçáo da obra de teoria política de mais fôlego escrita por Nicolau Maquiavel. A escrita do livro começou provavelmente em 27 a.C., e dos 142 livros escritos sobreviveram para consulta dos contemporâneos apenas alguns. De forma completa, os livros 1-10, 21-30 e 41-45. Os demais foram conservados apenas em forma de resumos preparados posteriormente. Apenas um dos 142 livros está irremediavelmente perdido. ${ }^{20}$ Meu interesse aqui é investigar os três primeiros livros de sua história. Pretendo incluí-los numa tradição de pensamento típica do Mediterrâneo

20 Sobre dados biográficos do autor e data do inicio da composição da obra, ver Introdução em Livy (19/9). Sobre os livros conservados e perdidos, ver Introduction em Livy (1919); Introdução em Livio (1989); e Introdução em Livio (2008). 
Antigo, especificamente àquela da qual faz parte Cícero, que constituiria um pensamento romano republicano. Isso pode ser notado na narrativa mestra que orienta a compreensão de ambos os autores sobre o significado de Roma, sua excelência e dinâmica de crescimento. A mesma narrativa localizável no Livro II do Tratado de Cícero sobre a coisa pública é esmiuçada por Lívio. A construção da república romana entre a fundaçáo da cidade e a Lei das XII Tábuas, descrita por Cipiáo, é retomada por um historiador.

A formaçáo da cidade é encaixada por Lívio na dinâmica histórica do Mediterrâneo Antigo. Rômulo, fundador de Roma e pai de todos os romanos, era descendente de Enéas, que, após a fuga de Troia, chega ao reino de Latino e se casa com sua filha. Geraçóes adiante, gêmeos da linhagem direta de Enéas são abandonados à morte pelo tio-avô que destrona o legítimo rei. Salvos por uma loba, são então criados de forma simples, tornando-se ambos vigorosos homens. Em dado momento, devolvem o trono ao avô e decidem fundar uma nova cidade, já que lideravam uma já razoável quantidade de homens espalhados pelos campos no entorno de Alba.

Após assassinar o irmão, Rômulo apodera-se sozinho do poder da nova cidade e torna-se rei. Seguem-se então mais seis reis, até a expulsão dos Tarquínios e o estabelecimento de uma magistratura para substituir o rei. O primeiro livro da história de Lívio apresenta um enredo aceito entre os romanos de seu tempo como a mais pura expressão da verdade, mesmo que com algumas variaçóes (PEREIRA, 2002). Ao acompanhar os detalhes da Roma sob a monarquia, entendo ser possível aquilatar a importância da monarquia no argumento de Lívio, tanto enquanto um regime que agregou inicialmente a cidade, quanto em termos de princípio fundamental para o estabelecimento e funcionamento da constituiçáo mista. Os primeiros atos de Rômulo são um indício disso.

Assim que assume o comando da recém-fundada cidade, Rômulo realiza rituais religiosos e em seguida inicia a construção da comunidade política: "Depois de ter realizado as cerimônias religiosas de acordo com o rito [de Hércules], Rômulo reuniu em assembleia aquele povo que só poderia vir a ser uma nação por liames jurídicos, e lhe deu leis." (AUC, 1.8). Após o estabelecimento das leis, Rômulo trata de torná-las sagradas aos olhos da massa que formaria uma cidade: "Compreendendo que, para torná-las sagradas perante aqueles homens rudes, ele próprio deveria inspirar-lhes respeito pelas insígnias 
de sua autoridade, entre outros distintivos fez-se acompanhar por doze lictores." (AUC, 1.8).

Em seguida, convencendo a multidáo de que uma nova raça ali brotaria, tornou a cidade refúgio de livres e escravos vindos de povos vizinhos, dotando-a de seu primeiro contingente populacional. Por último, criou um conselho, escolhendo cem cidadáos para ocupá-lo, dando-lhe o nome de patres (AUC, 1.8). Elementos considerados necessários para constituir a comunidade livre que caracterizaria a forma de governo tipicamente romana, logo republicana, foram assim criados. A comunidade política foi estabelecida por leis, que adiante seráo o esteio da liberdade. Foram conferidos signos para a identificação da populaçáo com a comunidade e o respeito ao rei, preservados depois na instituição do consulado, e um conselho foi constituído, colaborando com o rei no governo.

Ao envolver-se na guerra com os sabinos, resultado do rapto de suas mulheres, têm-se uma nova sequência de acontecimentos que devem ser aqui considerados. ${ }^{21}$ Quando a paz é celebrada com os sabinos, seu rei, Tácio, divide o poder com Rômulo - daí os romanos passarem a chamar-se quirites -, além de haver a criação de uma nova instituiçáo política: a divisão da cidade em três tribus, por sua vez divididas cada uma em dez curias (AUC, 1.13). Este é um dos primeiros sinais das constantes reformulaçóes de graus e distinçôes entre os romanos.

Ao longo dos próximos dois séculos de sua história, serão feitos arranjos institucionais criando e reformando as magistraturas da cidade, e o papel dos reis é relevante nesse processo. A república é sua obra também, seja nas açóes virtuosas dos bons reis, que instituíram práticas ou normas que posteriormente seriam incorporadas à cidade livre; seja nas práticas tirânicas de alguns, em especial ao comportamento dos Tarquínios, que finalmente ensejaram sua expulsão e tornaram o título de rei odioso aos romanos. Ele nunca mais será usado, nem mesmo quando um Império sucede a República.

Os sete reis de Roma enfeixam as boas e más características do governo de um só. Vou explorar os significados de três eventos, além da já referida circunstância da fundaçáa da cidade: o estabelecimento da civilidade promovido por

21 Sobre o Rapto das Sabinas, ver AUC (1.9). 
Numa Pompílio (716-673 a.C.); o primeiro rei a não contar com o sufrágio para ocupar o trono, Sérvio Túlio (578-535 a.C.), ao mesmo tempo promotor de reformas políticas fundamentais; e o reinado de Tarquínio, que, além de exemplificar a tirania no pensamento político romano, criou as circunstâncias que permitiram a extinção da monarquia em Roma.

Ao morrer, Rômulo é pranteado pela juventude romana, que, após momentos de medo, passa a saudá-lo como deus e pai da cidade, o que é confirmado adiante pela sua apariçáo a Próculo Júlio, anunciando sua vontade de que Roma se transformasse na capital do mundo (AUC, 1.16). Ao ter que escolher um novo rei, criou-se um impasse entre os romanos de origem sabina e aqueles mais antigos. Apesar dessa divergência, todos queriam novo rei, pois "[...] ainda não haviam provado o doce gosto da liberdade" (AUC, 1.17). A questão foi resolvida quando o governo foi compartilhado através dos senadores. Foram divididos em dez decúrias, sendo que cada uma indicaria um representante para governar durante cinco dias, quando entáo novo indicado ocuparia o trono. $\mathrm{O}$ arranjo criou o termo interregno e começou a descontentar a plebe, que agora alegava ter cem senhores em vez de um: "[a plebe] Parecia disposta a náo tolerar mais que um rei, e um rei escolhido por ela." (AUC, 1.17). O Senado aquiesce, reservando-se o direito de referendar a escolha popular. $\mathrm{O}$ povo, satisfeito com a situaçáo, confere ao Senado o direito da escolha (AUC, 1.17). A escolha de Numa Pompílio é autorizada pela sua reconhecida justiça e religiosidade. Ele vence a resistência dos romanos mais antigos, e um sabino reinará em Roma.

Do ponto de vista político, Numa Pompílio cria e organiza o calendário da cidade, organiza o território e delimita propriedades (AUC, 1.19-21). Do ponto de vista religioso, constrói templos e dota a cidade de uma série de ritos. Estabelece, como indicado, critérios de civilidade que elevam os romanos entre os povos respeitáveis da regiāo (AUC, 1.21). Ao suceder Rômulo e caracterizar seu governo como pacífico e cultivador de valores elevados, Numa Pompílio confere aos romanos um caráter intrinsecamente valoroso, que adiante será expresso no elogio constante entre os escritores da geração de Cícero e Lívio do mos maiorum, o costume dos antepassados. ${ }^{22}$ Séculos depois,

22 Sobre o significado de mos maiorum, ver Pereira (2002, p. 357-36I). No tratado sobre a velhice, de Cicero, Catão é a encarnação desses costumes. Ver Cícero (1997). 
é nesse quadro referencial próprio que os escritores romanos cultivarão as influências intelectuais vindas da Hélade.

Desde a instituiçãa das tribos e cúrias, Roma é uma monarquia em que o rei náo exerce as prerrogativas de governo sem a participação dos patrícios. No entanto, o primeiro rei a conquistar trono sem eleiçóes promoverá reformas que modificaráo de forma relevante a dinâmica política de Roma. Criado no palácio real, Sérvio Túlio sucede Tarquínio Prisco através de um ardil de Tanaquil, esposa do rei. ${ }^{23}$ Filho de servos, sem ligaçáo com a família do rei, será a distinçáo no campo de batalha que granjeará a autoridade suficiente para pretender realizar "[...] a mais considerável das obras realizadas em tempo de paz. Assim como Numa foi o fundador de nossas instituiçóes religiosas, a posteridade atribui a Sérvio a divisáo da sociedade em classes, que distingue os diversos graus de dignidade e fortuna." (AUC, 1.42). As reformas seriam feitas sobre o censo, onde patrícios e plebeus contribuiriam para o erário de acordo com suas rendas, tendo uma respectiva participação no governo, através das novas tribos divididas em cinco classes e 193 centúrias (AUC, 1.42-43). O estabelecimento de uma participaçáo censitária no governo da cidade rompe com o privilégio da antiga nobreza. Essa nova organizaçáo materializa-se numa nova assembleia popular, os comitia curiata, formada por patrícios e plebeus (PETIT, 2003). A monarquia romana estende alguma dose de cidadania a todos os indivíduos sob seu governo, capacitando a plebe ao envolvimento com os cargos públicos, situação inexistente antes da reforma ${ }^{24}$ (PETIT, 2003).

O sucessor de Sérvio Túlio teria também um papel relevante a cumprir na história de Roma. Tornando o título de rei odioso entre os romanos através de um governo tirânico, Tarquínio, o Soberbo, ${ }^{25}$ estará diretamente implicado no fim da monarquia em Roma. Assumindo o trono através de crimes, Tarquínio estabelece uma tirania: manda assassinar senadores que haviam apoiado Sérvio Túlio, cerca-se de guarda-costas, reina sem o sufrágio do povo e sem a aprovaçáo

23 Sobre as circunstâncias da criação de Sérvio Túlio, ver AUC (1.39); para as circunstâncias de seu acesso ao trono, ver AUC (I.4I).

24 Mesmo apontado para direções políticas e institucionais que caracterizariam as evidentes limitações das prerrogativas da plebe. mesmo com a instituição dos Tribunos da Plebe: "For Livy, the tribunes are initially a sort of shield, a largely protective weapon - not a sword, a primarily offensive weapon. It is quite possible for the plebs to be free with only a shield to protect them, and not to have proactive power." (KAPUST, 2004, p. 393).

25 Cognominado Soberbo por ter negado sepultura ao sogro. Sérvio Túlio, alegando que Rômulo também não havia sido enterrado (AUC, I.4I). 
dos senadores, torna-se único juiz em condenações à pena máxima, confisca bens, diminui o número de senadores e náo os consulta para assuntos de governo (AUC, 1.49).

Seu ato tirânico final foi condescender com o filho que viola Lucrécia, a mais virtuosa das romanas. ${ }^{26} \mathrm{O}$ crime seria entáo o pretexto para a expulsão dos reis de Roma, numa revolta aristocrática liderada por Lúcio Júnio Bruto, que, com o punhal utilizado por Lucrécia para cometer suicídio depois da infâmia nas mãos, exclama:

Por este sangue tão puro antes de ser manchado pelo crime do príncipe, eu juro e vos tomo como testemunhas, ó deuses, que hei de expulsar Lúcio Tarquínio Soberbo, ele, sua criminosa esposa e toda sua descendência, pelo ferro, pelo fogo, por todos os meios que estiverem em meu poder. Nem eles nem outro qualquer há de reinar em Roma. (AUC, 1.59).

A cidade é tomada pelo tumulto quando a notícia do estupro se espalha. $\mathrm{O}$ povo amotina-se contra a violência do príncipe, e jovens aristocratas apoiam Bruto, Lucrécio e Valério. Duzentos e quarenta e quatro anos depois da sua fundaçáo, Roma é libertada e dois magistrados sáo eleitos para ocupar o lugar do rei, Lúcio Júnio Bruto e Lúcio Tarquínio Colatino (AUC, 1.59-60). ${ }^{27}$

Inicia-se entáo novo período da história de Roma. A monarquia é derrubada, e o governo livre que virá em seguida se sustentará em grande medida nas instituiçóes criadas durante o período monárquico. A liberdade dos romanos começou a ser esboçada durante o governo dos reis. Os termos utilizados por Lívio para descrever a mudança de regime político em Roma sáo uma evidência textual dessa assertiva.

Lívio inicia o segundo livro de sua História anunciando que abordará a nova liberdade experimentada pelo povo romano, suas conquistas em tempo de paz e guerra, os magistrados eleitos anualmente e leis dotadas de mais autoridade que os próprios homens, uma liberdade ainda mais apreciada em virtude da tirania instalada pelo último rei (AUC, 2.1). Acrescenta que "[...] seus antecessores haviam reinado de tal modo que a posteridade merecidamente os considerou a todos fundadores da cidade, ou, pelo menos, de certos

26 Sobre a caracterização de Lucrécia, ver AUC (1.57).

27 Livio comete uma anacronia ao nomear consules os dois novos magistrados. Eles seriam assim nomeados depois dos decênviros. De inicio, foram nomeados pretores (LIVY, 1919, p. 208, nota I). 
bairros criados para abrigar a multidáo sempre crescente, que era atraída pelos reis" (AUC, 2.1). Na sequência, Lívio credita ainda à monarquia um papel aglutinador para a cidade nascente, afirmando que teria sido prejudicial aos romanos experimentar uma liberdade prematura. Foi necessária a contenção das agitaçóes entre um povo rude, obtida pelas insígnias da realeza. A comunidade poderia ter sido destruída se náo tivesse contado com governos calmos e moderados de seus reis, permitindo que Roma chegasse à maturidade e pudesse entáo suportar "o doce fruto da liberdade" (AUC, 2.1).

Lívio relaciona liberdade com a expulsão dos reis desde o livro anterior, mas apresenta uma explicação precisa para essa caracterizaçáo num trecho que, apesar de longo, merece aqui ser apresentado integralmente:

Além do mais, se a origem da liberdade se há de fixar nessa época, foi antes porque a duração do mandato consular se limitou a um ano e não porque se restringiu sob qualquer aspecto o poder real. Os primeiros cônsules mantiveram todos os direitos e todas as insígnias da realeza. Apenas procurou-se evitar que ambos os cônsules dispusessem dos fasces ao mesmo tempo, para não parecerem duas vezes mais temíveis. (AUC, 2.I).

Bruto é o primeiro a empunhar os fasces. Aproveitando-se do entusiasmo popular pela recente liberdade, obriga todos os romanos a jurar jamais aceitar reis em Roma novamente (AUC, 2.1). Essa promessa faz com que todos os Tarquínios sejam expulsos de Roma, quando Tarquínio Colatino passa a empunhar os fasces e torna-se suspeito de querer ocupar um trono em Roma novamente (AUC, 2.2). O povo romano considerava uma ameaça à nova liberdade a permanência de Tarquínios na cidade, ainda mais com um deles ocupando a principal magistratura.

A criaçáo de duas magistraturas eleitas anualmente para ocupar o papel dos reis é apenas o primeiro ato para dotar a cidade de magistraturas que pudessem equilibrar o governo entre diferentes setores sociais. A plebe terá a sua magistratura, e adiante terá o direito de ocupar qualquer outra, inclusive o consulado. A criação dos tribunos da plebe é um caso paradigmático.

A prisáo e escravidáo por dívidas foram o princípio de uma agitaçáo popular que consumiu Roma durante anos. A plebe alegava ser oprimida em sua própria pátria, quando era obrigada a lutar pela liberdade fora dela. A situaçáo acaba desembocando numa revolta motivada pela situaçáo abjeta em que um cidadáo que havia lutado pela cidade se encontrava (AUC, 2.23). As 
dissensóes entre a plebe e o governo da cidade acirram-se com as constantes tergiversaçóes de patrícios e cônsules em conferir direitos e proteçáo ao povo (AUC, 2.27). Uma conspiração popular leva o conflito ao Senado, onde duas opinióes sobre como enquadrar a plebe na dinâmica do governo se batem pelo estabelecimento da linha de ação da cidade em relação ao problema (AUC, 2.29). Quando a plebe retira-se da cidade, parece o fim da comunidade política fundada séculos antes. Roma é deixada sem proteção contra o inimigo que se avizinha. A plebe deixara a defesa da cidade com os patrícios, arvorados em senhores únicos de Roma (AUC, 2.33). Para reconciliar plebeus e patrícios e permitir a continuidade da comunidade política, são entáo criados os tribunis plebis, dois magistrados invioláveis que não poderiam ser escolhidos entre patrícios. Seu caráter sacrossanto os capacitaria a proteger a plebe contra a opressão de cônsules e senadores (AUC, 2.33).

A criação dos tribunos da plebe é passo fundamental para o estabelecimento de um governo misto, formado de maneira equilibrada por princípios constitucionais monárquicos, aristocráticos e democráticos. Para que o tipo de governo que será louvado por republicanos esteja completamente formado, resta que as leis sejam devidamente estabelecidas e conhecidas por toda a populaçáo. Esse é papel que caberá à Lei das XII Tábuas.

As tensóes entre patrícios e plebeus acabam exasperando toda a cidade. $\mathrm{O}$ aumento das prerrogativas da plebe incomoda o patriciado, obrigado agora a partilhar as decisóes, acusando os tribunos de provocar as prerrogativas de cônsules e senadores, uma reaçáo que pretende o retorno da dinâmica política anterior ao estabelecimento dos tribunos da plebe. Mas a população não está disposta a ser novamente escravizada, situação que seria engendrada pela sua náo participaçáo no governo. A situaçáo chega ao ponto de patrícios e plebeus acordarem a redaçáo de uma nova lei (AUC, 3.31). A plebe propóe entáo a indicaçáo de uma comissáo mista encarregada de definir os termos de uma nova legislação, capaz de atender aos interesses dos dois lados, assegurando assim liberdade a todos. A proposta é de agrado ao patriciado, que, no entanto, exige que a elaboração da legislação ficasse a cargo de patrícios. Como ambos os lados concordaram com a necessidade de uma legislaçáo, apesar de discordar em como redigi-la, foi enviada uma legação a Atenas para consultar as leis de Sólon e estudar as diferentes instituiçóes, costumes e leis das cidades gregas (AUC, 3.31). 
Com o retorno dos legados, abre-se a discussão de como proceder à redação das leis. Nomeiam-se então decênviros, encarregados de redigir as leis, sob a condição de que apenas patrícios participaráo da tarefa, sendo interditada a ab-rogaçáo de parte da legislação antiga que era de interesse plebeu (AUC, 3.33). Assim, 302 anos após a fundaçáo, Roma passa por nova mudança de governo. Assim como o poder havia passado dos reis aos cônsules, ele agora era passado dos cônsules aos decênviros. Cada um revezava-se na administraçáo da justiça, e a harmonia e equidade com que compartilharam das prerrogativas permitiram a elaboração de dez tábuas com a legislação que refunda Roma. Redigida com consultas à plebe, a lei das dez tábuas foi considerada perfeita e aprovada pelas assembleias da cidade, constituindo-se, segundo Lívio, na fonte de todo o direito público e privado dos $\operatorname{romanos}^{28}$ (AUC, 3.34). O acréscimo de duas novas tábuas é o enredo de mais um avanço da tirania, brotando da concentraçáo de prerrogativas de governo em máos de poucos.

Ápio Cláudio, sendo popular entre a plebe, havia sido escolhido presidente dos decênviros (AUC, 3.34), mas viu no pretexto de elaborar mais duas tábuas a possibilidade de reduzir a cidade à nova servidáo. Novos decênviros foram eleitos num processo eleitoral maculado, gerando uma representaçáo menos respeitável que a do ano anterior (AUC, 3.35). Ápio tornou-se líder de um grupo de cidadáos que aspirava a estabelecer um governo arbitrário em Roma. Os decênviros passaram a comportar-se como dez reis, aterrorizando patrícios e plebeus. Logo, as arbitrariedades recaíram exclusivamente sobre os plebeus. Corria em Roma o boato de que os decênviros conspiravam para estabelecer uma tirania perene na cidade (AUC, 3.36). Os senadores nada fizeram para conter a sanha tirânica dos decênviros, pois os odiavam tanto quanto à plebe, que culpavam por ter tal desejo de liberdade que arrastara a cidade ao tumulto e ao controle decenverial. Apesar de as duas tábuas terem sido adicionadas às dez primeiras, náo se falava em eleiçáo. Além disso, a juventude patrícia fazia o papel que antes coube à plebe: protegia os decênviros, que avançaram sobre os bens e a dignidade da plebe com a anuência do patriciado (AUC, 3.38).

Essa situação deságua numa espécie de repetição dos eventos que levaram à derrubada da monarquia e ao estabelecimento dos tribunos da plebe. Ápio

28 A crítica moderna endossa a visão de Livio, acrescentando que a lei parece ter sido uma consagração de antigos costumes, a partir de então dotados de nova força (PETIT, 2003). 
Cláudio comete o mesmo crime que Sexto Tarquínio: viola uma romana virtuosa (AUC, 3.44). Uma correia de acontecimentos leva a um novo abandono da cidade pela plebe, ultrajada novamente pela arrogância e opressão dos patrícios (AUC, 3.52). Novamente, legados sáo enviados à plebe, que exige o retorno das garantias e dos acordos feitos para sua liberdade. O Senado acata o pleito, os decênviros pedem demissáo e sáo realizadas eleiçóes para novos tribunos da plebe (AUC, 3.54). Em seguida, são nomeados novos cônsules (AUC, 3.55), as doze tábuas são apresentadas ao povo e os decênviros são julgados (AUC, 3.56-57).

As tensóes entre patrícios e plebeus náo cessam com esses eventos, mas, desse ponto em diante, seráo sempre canalizadas por uma série de magistraturas e instituiçóes alicerçadas em princípios constitucionais monárquicos, aristocráticos e democráticos. A engenharia político-institucional convencionalmente nomeada constituiçáo mista estava montada e funcionaria com poucas e irrelevantes modificaçóes até o fim da república. A comunidade livre romana estava alicerçada em decisóes tomadas durante as circunstâncias da fundaçáo e formaçáo da cidade. A res publica foi um produto da história dos romanos.

\section{Considerações finais}

A teoria política contemporânea demonstra atualmente um interesse renovado nos escritos vinculados à tradiçáo republicana de pensamento político. Entre as fontes para essa consulta, um conjunto de escritores romanos do período final da república e início do principado constitui parte relevante, sendo considerados clássicos da tradiçáo. Cícero e Tito Lívio estáo entre os mais importantes clássicos do pensamento republicano.

Apresentei elementos que podem incrementar o modo como a Teoria Política contemporânea acessa os clássicos. Sustento que esse acesso deve evitar a criaçáo de visóes anacrônicas sobre os significados dos escritos dos antigos romanos, já que pouco diria sobre os significados que os próprios autores poderiam ter atribuído aos seus escritos. Possíveis incompreensóes sobre os autores romanos antigos podem ter sido herdadas da crítica moderna, que criou o republicanismo, antes decalcando nos escritos antigos suas próprias ideias e formulaçóes, do que os tomando em seus próprios termos. $\mathrm{O}$ antimonarquismo é exemplar nesse aspecto. 
Modernamente, em especial na linguagem ordinária, o termo república tornou-se equivalente de um regime político não monárquico. E somente isso. Uma palavra vazia, perto da variedade de sentidos que lhe foram atribuídos tanto pelos antigos romanos quanto pelos homens do início da modernidade. A consulta aos dois primeiros livros do Tratado de Cícero sobre a coisa pública e aos três primeiros livros da História de Lívio indica e exemplifica perfeitamente que mesmo esse significado pretensamente definidor do republicanismo moderno pode náo encontrar amparo nos escritos romanos antigos.

A monarquia em ambos os autores não é apenas elemento constituinte das ideias políticas típicas dos romanos, mas fundamental. A monarquia foi um fator agregador inicial do povo romano, que náo poderia aproveitar adiante a liberdade sem a criação prévia desse amálgama. Os reis de Roma foram sempre considerados pais da cidade, responsáveis pela construçáo da comunidade. Com sua expulsão de Roma, são mantidas suas prerrogativas, materializadas na criação de uma magistratura eleita anualmente para representá-los. Com a criação de uma magistratura para representar os plebeus, somada ao já existente Senado, Roma estabelece uma dinâmica de equilíbrio institucional que gera um regime típico de governo. Cada uma das formas puras de governo terá participaçáo na conduçáo da política em Roma. Isso constituirá o princípio da criaçáo máxima dos romanos em termos de pensamento político: a Constituiçáo Mista.

Caso realmente exista uma tradiçâo republicana de pensamento político, ela é produto de diversas geraçóes intelectuais, esparramadas por dois milênios de história. Se pretendermos nos nutrir das respostas dadas por outros homens sobre outros problemas para solucionar nossos próprios dilemas, convém tentar compreender da melhor maneira possível o dito no passado. Se nos contentarmos em decalcar nossas próprias ideias em escritos do passado, náo seremos capazes de compreendê-los. Logo, seremos incapazes de torná-los úteis às nossas comunidades políticas.

\section{Referências}

ANDO, C. 'A Dwelling Beyond violence': on the uses and disadvantages of history for contemporary republicans. History of Political Thought, v. 31, n. 2, p. 183-220, 2010.

BALOT, R. Polybius' advice to the Imperial Republic. Political Theory, v. 38, n. 4, p. 483-509, 2010. 
BERLIN, I. Dois conceitos de liberdade. In: Estudos sobre a humanidade: uma antologia de ensaios. São Paulo: Companhia das Letras, 2012. p. 226-272.

BEVIR, M. On tradition. Humanitas, v. 13, n. 2, p. 28-53, 2000.

CÍCERO. The Republic; laws. Traduçâo de Clinton W. Keyes. Cambridge, London: Harvard University Press, 1928.

Da República. Tradução de Amador Cisneiros. São Paulo: Edipro, 1995.

Tratado da República. Tradução, introdução e notas de Francisco de Oliveira. Portugal: Círculo de Leitores e Tema e Debates, 2008.

Saber envelhecer seguido de Lélio, ou A amizade. Traduçáo de Paulo Neves. Porto Alegre: L\&PM Editores, 1997.

DOUGLASS, R. Montesquieu and modern republicanism. Political Studies, v. 60, n. 3, p. 703-719, Oct. 2012.

KAPUST, D. Skinner, Pettit e Livy: the conflict of the orders and the ambiguity of republican liberty. History of Political Thought, v. 25, n. 3, p. 378-401, 2004.

Republicanism, rhetoric, and roman political thought: Sallust, Livy, and Tacitus. New York: Cambridge University Press, 2011.

LIVY. History of Rome - books I-II. Translated by B. O. Foster. Cambridge, London: Harvard University Press, 1919.

History of Rome - books III-IV. Translated by B. O. Foster. Cambridge, London: Harvard University Press, 1922.

LÍVIO, T. História de Roma, Vol I. Tradução de Paulo Matos Peixoto. São Paulo: Paumape, 1989. História de Roma - a Monarquia. Tradução de Monica Costa Vitorino. Belo Horizonte: Crisálida, 2008.

MADDOX, G. The limits of neo-roman liberty. History of Political Thought, v. 23, n. 3, p. 418-431, 2002.

PEREIRA, M. H. da R. Estudos de história da cultura clássica. Volume II - Cultura romana. Lisboa: Fundação Calouste Gulbenkian, 2002.

PETIT, E. Tratado elementar de Direito Romano. Tradução de Jorge Luís Custódio Porto. Campinas: Russel Editores, 2003. 
PETTIT, P. Republicanismo: una teoría sobre la libertad y el gobierno. Barcelona: Paidós, 1999.

PLATÃO. A república. Traduçáo de J. Guinsburg. São Paulo: Perspectiva, 2006.

SKINNER, Q. Liberdade antes do liberalismo. Sáo Paulo: Ed. da Unesp, 1999.

The paradoxes of political liberty: the tanner lectures on human values, Harvard University, 1984.

. A third concept of liberty. Proceedings of the British Academy, v. 117, p. 237-68, 2002.

STRAUMANN, B. Constitutional thought in the late Roman republic. History of Political Thought, v. 32, n. 2, p. 281-292, 2011.

WALKER, W. Sallust and Skinner on civil liberty. European Journal of Political Theory, v. 5, n. 3, p. 237-259, 2006.

WIRSZUBSKI, C. Libertas as a political idea at Rome during the late republic and early principate. Cambridge: Cambridge University Press, 1968.

WOOD, N. Cicero's social and political thought. Berkeley: University of California Press, 1991.

Recebido em: 20/02/2014

Aprovado em: 22/05/2014

\section{Monarchy among republicans}

\section{Abstract}

Contemporary political theory has been increasingly challenged by formulations grounded on republican ideas. Current theorists have claimed that the genesis of this tradition in political thought can be found in the prevailing political and moral notions of the ancient roman Republic. My goal in this paper is to evaluate the first three books of The history of Rome, by Livy, and the first two books of On the Republic, by Cicero, and investigate the importance of monarchy in their arguments. I argue that a precise understanding of the significance of the initial stage of the history of the city and this constitutional principle to the idea of Mixed Constitution can enrich insight into key elements of the republican tradition of political thought.

Keywords: Political theory. Republicanism. Monarchy. Rome. 